\title{
HUBUNGAN JENIS SEDIMEN DENGAN KERAPATAN MANGROVE DI DESA TIMBULSLOKO, DEMAK
}

\author{
Correlation between Type of Sediment and Mangrove Density \\ at Timbulsloko Village, Demak
}

\author{
Fadhil Mauludi, Bambang Sulardiono*), Haeruddin
}

Program Studi Manajemen Sumberdaya Perairan

Departemen Sumberdaya Akuatik Fakultas Perikanan dan Ilmu Kelautan, Universitas Diponegoro

Jl. Prof. Soedharto, SH, Tembalang, Semarang, Jawa Tengah-50275, Telp/Fax. +6224 7474698

E-mail : fadhil.mld@gmail.com

\begin{abstract}
ABSTRAK
Timbulsloko adalah salah satu desa yang berada di Kecamatan Sayung, Demak. Daerah ini menjadi salah satu kawasan yang mengalami erosi secara terus menerus yang mengakibatkan luas daerahnya menjadi semakin berkurang. Dominasi mangrove yang ditemukan di desa ini adalah Rhizophora sp. dan Avicennia sp.. Tujuan dari penelitian ini adalah untuk mengetahui jenis sedimen, kerapatan mangrove serta hubungan jenis sedimen dengan kerapatan mangrove di Desa Timbulsloko, Demak. Penelitian ini dilaksanakan pada bulan April 2018. Metode penelitian yang digunakan adalah metode kuantitatif yang bersifat deskriptif dengan pemilihan lokasi penelitian menggunakan teknik purposive sampling. Lokasi sampling dibagi menjadi 3 stasiun, tiap stasiun dibagi menjadi 6 titik sampling. Hasil yang diperoleh dari jenis sedimen ketiga stasiun didominasi tekstur pasir dengan persentase pasir stasiun $168,78 \%$, pasir stasiun $268,42 \%$, dan pasir stasiun $365,91 \%$. Bahan organik sedimen pada stasiun 1 berkisar 1,08-1,48\%, stasiun 2 berkisar 0,28-1,6\%, dan stasiun 3 berkisar 0,88-2,32\%. Salinitas sedimen pada ketiga stasiun berkisar antara 29-30\%. Kerapatan mangrove di lokasi penelitian Desa Timbulsloko didominasi oleh jenis mangrove Avicennia sp.. Nilai kerapatan mangrove stasiun 1 berkisar 2066 - 4550 pohon/ha, stasiun 2 berkisar 2519 - 10000 pohon/ha, dan stasiun 3 berkisar 5986 - 18511 pohon/ha. Hubungan jenis sedimen dengan kerapatan mangrove jika dilihat dari analisa PCA, berdasarkan nilai loading factor kedua faktor yang terbentuk pada ketiga stasiun menunjukkan tingginya korelasi antar variabel. Sedangkan, jika dilihat dari hasil analisa regresi linear berganda menunjukkan bahwa hubungan jenis sedimen dengan kerapatan mangrove di ketiga stasiun mempunyai hubungan yang sangat kuat.
\end{abstract}

Kata Kunci: Jenis Sedimen; Kerapatan Mangrove; Desa Timbulsloko; Demak

\section{ABSTRACT}

Timbulsloko is one of the villages located in Sayung District, Demak. This area became one of the areas that experienced continuous erotion which resulted the area became decreasing. The dominance of mangroves found in this area is Rhizophora sp. and Avicennia sp. The purpose of this research is to know the type of sediment texture, mangrove density and the relation of sediment texture with mangrove density in Timbulsloko village, Demak. This study was conducted in April 2018. The method of this research is descriptive quantitative method and using purposive sampling technique. Sampling area is divided into 3 stations, each station divided into 6 sampling points. The results showed that sediment types from three stations were dominated by sand texture with the percentage of station 1 sand $68.78 \%$, station sand $268.42 \%$, and station sand $365.91 \%$. Sediment organic material at station 1 ranged from 1.08 to $1.48 \%$, station 2 ranged from 0.28 to $1.6 \%$, and station 3 ranged from 0.88 to 2.32\%. Sediment salinity in three stations ranged from 29-30\%. Mangrove density in Timbulsloko Village is dominated by Avicennia sp.. The mangrove density values at station 1 ranged from 2066 to 4550 trees / hectare, station 2 ranged from 2519 to 10000 trees / hectare, and station 3 ranged from 5986 to 18511 trees / hectare. The relationship between the type of sediment and the density of mangroves when viewed from the PCA analysis, based on the value of loading factors from two factors formed on three stations showed the high correlation between variables. Meanwhile, when viewed from the results of multiple linear regression analysis shows that the relationship between the type of sediment and the density of mangroves in three stations has a very strong relationship.

Keywords: Type of Sediment; Mangrove Density; Timbulsloko Village; Demak

*) Penulis penanggungjawab

\section{PENDAHULUAN}

Wilayah pesisir adalah wilayah pertemuan antara daratan dan laut, ke arah darat meliputi bagian daratan yang masih dipengaruhi oleh sifat-sifat laut seperti pasang surut, angin laut dan intrusi garam, sedangkan ke arah laut mencakup bagian laut yang masih dipengaruhi oleh proses alami yang ada di darat seperti sedimentasi dan aliran air tawar serta daerah yang dipengaruhi oleh kegiatan-kegiatan manusia di daratan. (Nontji, 2002). Pesisir pantai merupakan daerah peralihan laut dan daratan. Kondisi tersebut menyebabkan wilayah pesisir selalu mengalami 
dinamika setiap mendapatkan tekanan dari berbagai aktivitas atau fenomena yang terjadi. Perubahan konfigurasi pantai di wilayah pesisir dapat disebabkan oleh kegiatan atau proses alami dan non alami (kegiatan manusia) baik yang berasal dari darat maupun dari laut. (Supriyanto, 2003 dalam Damaywanti, 2011). Dampak perubahan iklim yang diakibatkan meningkatnya suhu udara di bumi berimplikasi pada semakin tinggi paras laut (sea level). Tingginya permukaan air laut dapat menyebabkan kerusakan alamiah disebabkan oleh aktivitas gelombang laut yang tinggi sehingga menyebabkan abrasi pada wilayah pesisir khususnya hutan mangrove. Hal ini berdampak pada kerentanan hutan mangrove di Desa Timbulsloko.

Desa Timbulsloko adalah desa yang berada di Kecamatan Sayung, Kabupaten Demak, Jawa Tengah. Desa ini memiliki luas wilayah 461 ha atau sekitar 5,85\% dari total luas wilayah Kecamatan Sayung. Menurut data Dinas Kelautan dan Perikanan Kabupaten Demak tahun 2009, Desa Timbulsloko memiliki pantai sepanjang $2 \mathrm{Km}$ dengan abrasi pantai yang terjadi seluas 74,47 ha dan luasan ekosistem mangrove dengan kondisi baik seluas 151 ha serta kondisi rusak 85 ha. Menurut Astra et al., (2014) pada sekitar tahun 2000, erosi mulai terjadi di pesisir Desa Timbulsloko, dan pada tahun 2013 desa tersebut telah kehilangan sekitar 400 - 1300 meter daerah pesisirnya. Menurut data Dinas Kelautan dan Perikanan Kabupaten Demak tahun 2015 distribusi dan luas sumberdaya hutan mangrove di wilayah pesisir Kabupaten Demak Desa Timbulsloko sebesar 99,42 ha.

Kondisi pesisir di Timbulsloko, Kabupaten Demak dapat dikatakan cukup memprihatinkan. Hal tersebut dikarenakan wilayah pesisir yang memiliki pantai bermangrove telah mengalami perubahan luas wilayahnya akibat pengaruh faktor lingkungan. Usaha yang dilakukan untuk memperoleh informasi mengenai kondisi sedimen dan mangrove yaitu dengan melakukan penelitian tentang kerapatan mangrove, tekstur sedimen, bahan organik sedimen, dan salinitas sedimen.

Tujuan dari penelitian ini adalah:

1. Mengetahui tipe tekstur sedimen mangrove di Desa Timbulsloko, Kecamatan Sayung, Demak.

2. Mengetahui nilai kerapatan mangrove yang ada di Desa Timbulsloko, Kecamatan Sayung, Demak.

3. Mengetahui hubungan antara jenis sedimen terhadap kerapatan mangrove di hutan mangrove Desa Timbulsloko, Kecamatan Sayung, Demak

\section{MATERI DAN METODE PENELITIAN}

Pengambilan sampel dilakukan pada 3 stasiun yang jumlahnya ditentukan dengan cara membuat 2 garis maya tegak lurus garis pantai. Jarak antar stasiun yaitu 20 meter dan setiap stasiun dilakukan 6 kali pengulangan. Menurut Keputusan Menteri Negara Lingkungan Hidup No 201 tahun 2004 dalam Susiana (2011), Kriteria Baku Kerapatan Mangrove yaitu dikatakan padat apabila kerapatannya $\geq 1.500$ pohon/ha. Kemudian akan dikatakan sedang apabila kerapatannya $\geq 1.000-1.500$ pohon/ha, dan akan dikatakan jarang apabila kerapatannya $\leq 1.000$ pohon/ha. Pada masing-masing stasiun dilakukan pengamatan tekstur sedimen, bahan organik sedimen, salinitas sedimen dan kerapatan ekosistem mangrove. Pengamatan kerapatan mangrove dengan menggunakan metode Point Quarter Method. Metode ini dilakukan pengukuran jarak antar individu tumbuhan atau jarak dari pohon yang dipilih secara acak terhadap individu-individu tumbuhan yang terdekat. Pada titik pengambilan sampel akan dibuat dua buah garis maya yang menjadikan titik tersebut sebagai pusat sehingga akan didapatkan empat buat kuadran. Pada tiap kuadran akan dipilih satu pohon yang terdekat dari titik pusat, kemudian akan diukur jaraknya. Pada keempat pohon terdekat itu juga akan dilakukan pencatatan jenis dan keliling batang pohon dan dilakukan pengamatan tekstur sedimen dan salinitas sedimen. Pengukuran vegetasi mangrove dilakukan dengan metode titik pusat kuadran (Point Quarter Method). Metode ini juga digunakan oleh Susiana (2011), apabila menggunakan Metode Point Centered Quarter akan mempermudah menghitung jumlah semua tegakan mangrove. Mangrove yang diukur adalah mangrove yang berada di Point Centered Quarter, dimana dipilih pohon yang paling dekat di setiap kuarter. Menurut Mitchell (2007), untuk menghitung kerapatan relatif suatu ekosistem hutan mangrove, maka akan menggunakan rumus-rumus sebagai berikut :

Menghitung jarak rata-rata antar pohon, dengan rumus :

Jarak rata-rata tiap pohon $(\hat{\mathrm{r}})=\frac{\sum \text { Jarak Pohon }}{\sum \text { Jumlah Pohon }}$

Menghitung kerapatan absolut total, dengan rumus :

Kerapatan Absolut Total $(\lambda)=\frac{1}{\mathrm{r}^{\wedge} 2}$

Kerapatan Absolut tiap spesies (pohon/ha) $=\frac{\text { Frekuensi Kemunculan Spesies }}{\text { Total kuadran }}$

Menghitung kerapatan relatif tiap spesies, dengan rumus :

Kerapatan Relatif tiap spesies $=\frac{\text { Jumlah Pohon }}{\text { Total Jumlah Pohon }} \times 100 \%$

Pengukuran tekstur sedimen dilakukan dengan menggunakan metode Buchanan, (1971) yaitu sampel sedimen yang telah diambil dari sampling lapangan diletakkan pada aluminium foil dan diberi label sebagai penanda sedimen antar titik sampling (stasiun). Sampel sedimen dikeringkan dengan menggunakan oven bersuhu tinggi $\left(220^{\circ} \mathrm{C}\right)$ selama \pm 4 jam lalu didinginkan. Sampel yang telah kering diambil, kemudian dihaluskan dengan mortar lalu ditimbang dengan 
menggunakan timbangan elektrik sebanyak 25 gram. Sampel sedimen yang sudah halus kemudian disaring untuk dipisahkan antara sand, silt, dan clay dengan sieve shaker yang memiliki sieve net $0,063 \mathrm{~mm}(63 \mu \mathrm{m})$. Sampel sedimen yang tidak lolos saringan dimasukkan kedalam gelas beker kecil, diberi label sand dan dikeringkan di oven pada suhu $220^{\circ} \mathrm{C}$. Sampel sedimen yang lolos saringan (silt dan clay) dimasukkan ke dalam gelas ukur 11 dan ditambahkan air sampai batas 11, ditutup dengan plastik bening kemudian dibolak-balik dan siap dilakukan pemipetan.

Pemipetan pertama berjarak $20 \mathrm{~cm}$ dari atas, setelah waktu 58 detik. Selanjutnya di taruh dalam gelas beker 50 ml. Pemipetan kedua setelah 1 menit 56 detik dan berjarak $10 \mathrm{~cm}$ dari pemipetan pertama. Pemipetan ketiga setelah 7 menit 44 detik dengan jarak yang sama pada pemipetan kedua. Pemipetan keempat setelah 31 menit dengan jarak pemipetan juga sama dengan pemipetan kedua, dan pemipetan kelima setelah 2 jam 3 menit dengan jarak pemipetan yang sama dengan pemipetan kedua. Selanjutnya seluruh hasil pemipetan dikeringkan lalu ditimbang. Pemipetan pertama adalah a gram, pemipetan kedua adalah b gram, pemipetan ketiga adalah c gram, pemipetan keempat adalah d gram, dan pemipetan kelima adalah e gram. Berat sedimen jenis silt dan clay ditentukan dengan cara :

Berat silt $=(a-b)+(b-c)+(c-d)+(d-e)$

Berat clay $=B T-$ berat sand - berat silt

Keterangan:

BT $=$ Berat total sampel yang digunakan (25 gram)

Perhitungan tekstur sedimen sand, silt, dan clay dengan rumus sebagai berikut:

- Fraksi sand didapat dari hasil penimbangan sampel sedimen yang tidak lolos pada sieve shaker kemudian dijumlahkan (berat total).

$$
\text { Persentase sand }=\frac{\text { Berat total }(g)}{25} \times 100 \%
$$

- Fraksi silt didapatkan dari hasil pemipetan sebanyak 5 kali dengan waktu yang berbeda. Masing-masing sampel yang telah dioven kemudian ditimbang beratnya lalu dikonversikan ke dalam persen.

Persentase silt $=\frac{\text { berat total fraksi silt }}{25} \times 100 \%$

- Fraksi clay

Persentase clay $=100 \%-\%$ sand $-\%$ silt

Selanjutnya hasil yang didapat dari metode Buchanan akan dianalisa menggunakan Segitiga Sheppard. Menurut Munandar et al., (2014), analisis karakteristik sedimen dengan menggunakan Segitiga Sheppard merupakan perhitungan yang didasarkan pada proporsi kandungan ukuran partikel kerikil, pasir, dan lumpur. Sistem klasifikasi ini berdasarkan Median diameter (Md). Sistem dari tiga komponen yang berjumlah 100\%. Diagram Sheppard mengikuti konversi semua diagram rangkap tiga. Sebagai contoh, lumpur berisi sedikitnya 75\% partikel-partikel ukuran lumpur. "Silt Sand" dan "Sandy Silt" berisi tidak lebih dari pada 20\% ukuran partikel "Clay" dan "Sand-Silt Clays" berisi sedikitnya 20\% dari setiap ketiga komponen-komponen.

Analisa bahan organik sedimen menggunakan prinsip gravimetrik metode Buchanan, (1971) yaitu dengan menimbang sedimen kering sebanyak 25 gram dengan cawan menggunakan timbangan elektrik. Masukkan cawan yang berisi sedimen ke dalam furnace kemudian hidupkan dan tunggu selama 6 jam. Suhu yang dibutuhkan dalam bahan organik sekitar $400^{\circ} \mathrm{C}-500^{\circ} \mathrm{C}$. Setelah 6 jam cawan dikeluarkan dari furnace dan tunggu hingga suhunya normal. Kemudian timbang kembali cawan yang telah dingin menggunakan timbangan elektronik lalu masukkan ke dalam rumus :

$$
\begin{aligned}
& \text { Berat BOT }=(B C K+B S)-\text { BSP } \ldots \ldots \ldots \ldots \\
& \qquad \text { Bahan Organik }=\frac{\text { Berat Bот }}{\text { Berat sampel }} \times 100 \% \\
& \text { Keterangan : } \\
& \text { BCK } \quad=\text { Berat Cawan Kosong (gram) } \\
& \text { BS } \quad=\text { Berat Sampel (gram) } \\
& \text { BSP = Berat Setelah Pijar (gram) }
\end{aligned}
$$

Pengukuran salinitas sedimen dilakukan dengan mengambil sampel sedimen pada setiap titik pengambilan sampel. Kemudian memasukkan sampel sedimen ke dalam spuit suntik yang ujungnya telah diberi kapas atau kertas 
saring. Langkah selanjutnya menekan spuit suntik tersebut hingga keluar air perasan. Air perasan yang keluar kemudian diteteskan pada refraktometer untuk dilihat nilai salinitasnya.

Analisa data yang digunakan dalam penelitian ini adalah Analisis Komponen Utama (Principal Component Analysis) dan regresi linear berganda menggunakan perangkat lunak SPSS versi 25. Analisa PCA ini digunakan untuk mengubah bentuk sejumlah variabel berkorelasi menjadi beberapa variabel yang berdiri sendiri atau tidak berkorelasi tanpa mengurangi atau menghilangkan informasi yang ada didalamnya. Variabel bebas yaitu sand, silt, clay, bahan organik dan salinitas, sedangkan untuk variabel tidak bebas yaitu kerapatan mangrove. Menurut Hendro et al., (2012), tujuan dari analisa PCA adalah untuk mereduksi variabel yang ada menjadi lebih sedikit tanpa harus kehilangan informasi yang termuat dalam data asli/awal. Data diolah dengan analisa regresi linear berganda untuk mengetahui besarnya hubungan dan pengaruh variabel bebas (independen) $\mathrm{X}_{1}$ (sand), $\mathrm{X}_{2}$ (silt), $\mathrm{X}_{3}\left(\right.$ clay), $\mathrm{X}_{4}$ (bahan organik), $\mathrm{X}_{5}$ (salinitas) terhadap variabel tidak bebas (dependen) Y (kerapatan mangrove).

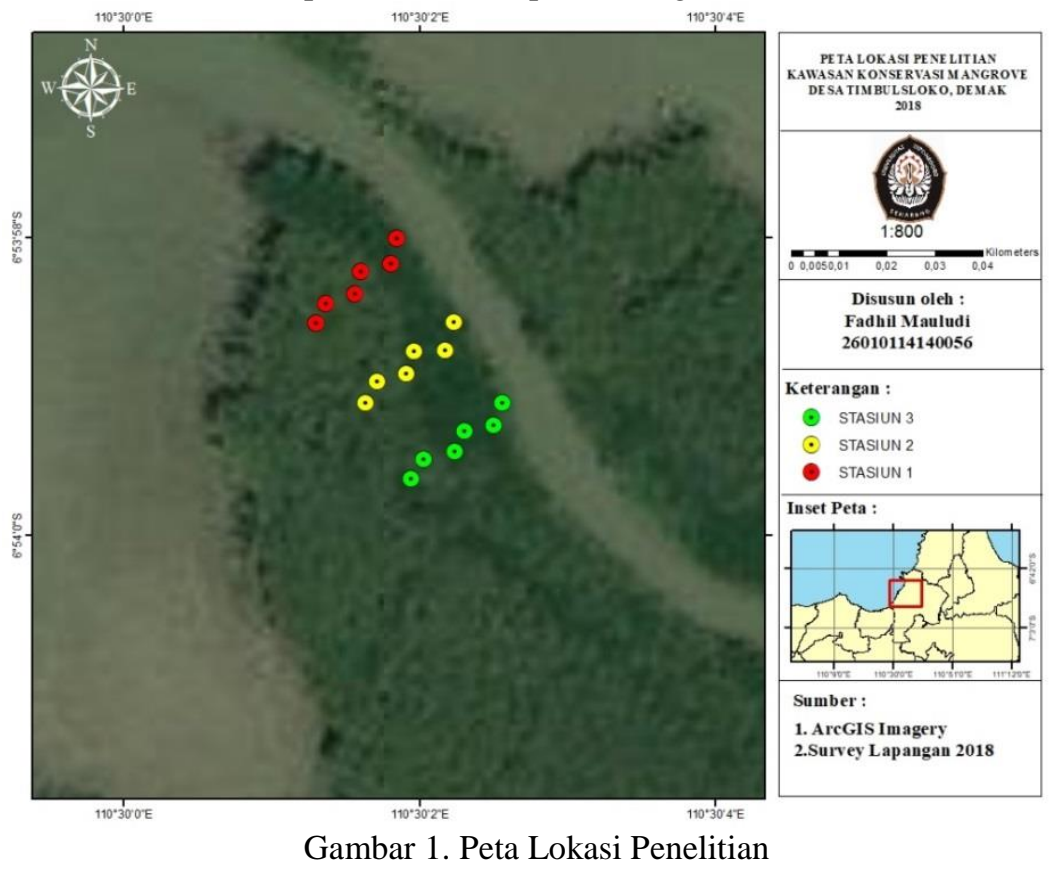

3. HASIL DAN PEMBAHASAN

Kerapatan Mangrove

Tabel 1. Hasil Kerapatan Mangrove di Desa Timbulsloko

\begin{tabular}{cccccc}
\hline Stasiun & Titik & $\begin{array}{c}\text { Kerapatan } \\
\text { (pohon/Ha) }\end{array}$ & $\begin{array}{c}\text { Diameter } \\
(\mathbf{c m})\end{array}$ & Kriteria Baku * & Komposisi Jenis Mangove \\
\hline \multirow{6}{*}{ I } & 1 & 2184 & $7,32-14,33$ & $>1500$ (rapat) & Rhizophora sp. dan Avicennia sp. \\
& 2 & 2066 & $8,28-9,87$ & $>1500$ (rapat) & Avicennia sp. \\
& 3 & 2415 & $4,78-11,46$ & $>1500$ (rapat) & Avicennia sp. \\
& 4 & 2184 & $7,69-11,46$ & $>1500$ (rapat) & Avicennia sp. \\
& 5 & 4550 & $4,78-7,96$ & $>1500$ (rapat) & Avicennia sp. \\
& 6 & 2777 & $6,75-8$ & $>1500$ (rapat) & Avicennia sp. \\
\hline \multirow{4}{*}{ II } & 1 & 2914 & $9,56-14,01$ & $>1500$ (rapat) & Rhizophora sp. dan Avicennia sp. \\
& 2 & 3440 & $8,6-13,38$ & $>1500$ (rapat) & Avicennia sp. \\
& 3 & 2519 & $7,69-13,49$ & $>1500$ (rapat) & Avicennia sp. \\
& 4 & 4176 & $4,14-7,32$ & $>1500$ (rapat) & Rhizophora sp. dan Avicennia sp. \\
& 5 & 3564 & $7,47-8,46$ & $>1500$ (rapat) & Rhizophora sp. dan Avicennia sp. \\
& 6 & 10000 & $3,82-9,87$ & $>1500$ (rapat) & Avicennia sp. \\
\hline \multirow{2}{*}{ III } & 1 & 5986 & $6,05-10,51$ & $>1500$ (rapat) & Avicennia sp. \\
& 2 & 8153 & $5,1-11,45$ & $>1500$ (rapat) & Avicennia sp. \\
& 3 & 18511 & $4,46-5,73$ & $>1500$ (rapat) & Avicennia sp. \\
& 4 & 10307 & $3,99-11,2$ & $>1500$ (rapat) & Avicennia sp. \\
& 5 & 8340 & $3,5-10,19$ & $>1500$ (rapat) & Avicennia sp. \\
& 6 & 14088 & $3,98-12$ & $>1500$ (rapat) & Avicennia sp.
\end{tabular}

Keterangan: $*=$ Keputusan Menteri Lingkungan Hidup nomor 201 Tahun 2004 


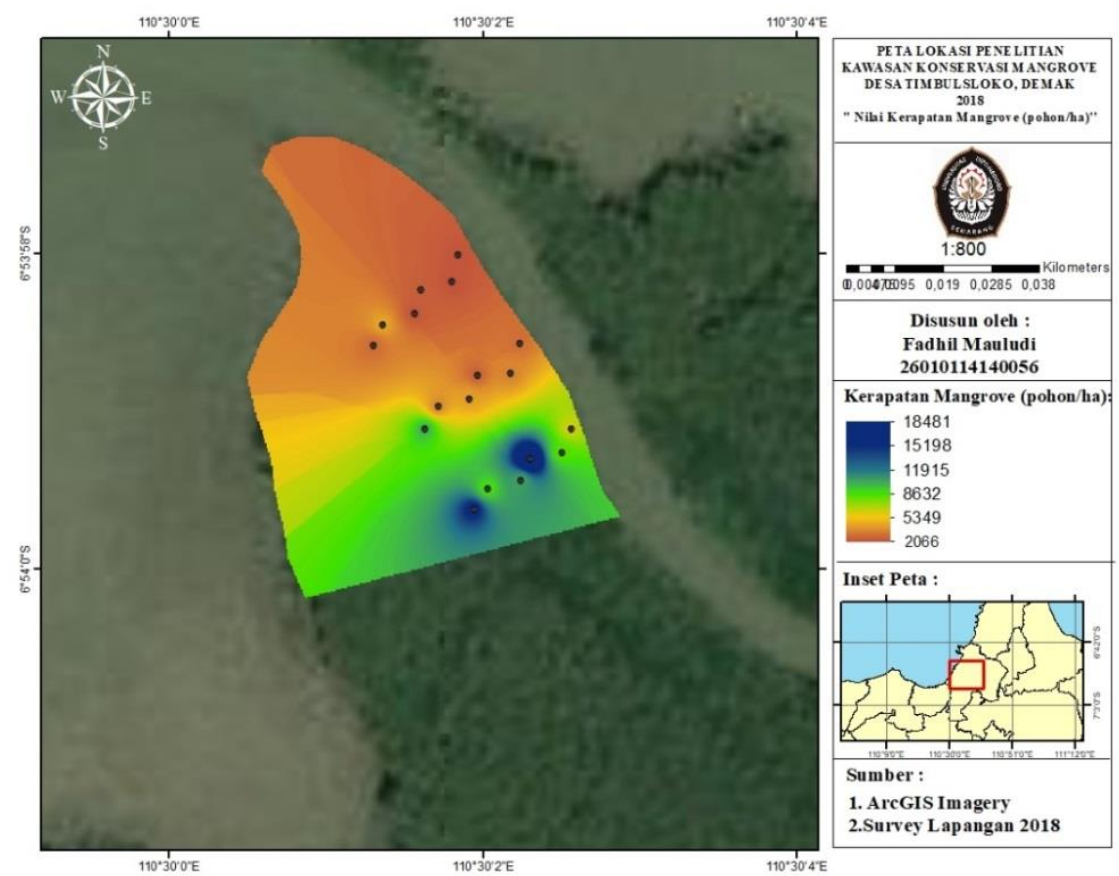

Gambar 2. Peta Gambaran Kerapatan Mangrove di Lokasi Penelitian Desa Timbulsloko, Demak

Pada stasiun 1 kerapatan hutan mangrove berkisar 2066 pohon/ha - 4550 pohon/ha. Pada stasiun 2 kerapatan hutan mangrove berkisar 2519 pohon/ha - 10000 pohon/ha. Sedangkan pada stasiun 3 kerapatan hutan mangrove berkisar 5986 pohon/ha - 18511 pohon/ha.

\section{Jenis Sedimen}

Hasil pengukuran jenis sedimen dapat dilihat pada Tabel 2.

Tabel 2. Hasil Pengukuran Jenis Sedimen Stasiun 1, 2, dan 3

\begin{tabular}{|c|c|c|c|c|c|c|c|}
\hline \multirow{2}{*}{ Stasiun } & \multirow{2}{*}{ Titik } & \multicolumn{3}{|c|}{ Persentase Butiran Sedimen (\%) } & \multirow{2}{*}{ Fraksi Sedimen } & \multirow{2}{*}{$\begin{array}{c}\text { Bahan } \\
\text { Organik }(\%)\end{array}$} & \multirow{2}{*}{$\begin{array}{c}\text { Salinitas } \\
\text { (\%o) }\end{array}$} \\
\hline & & Sand & Silt & Clay & & & \\
\hline \multirow{6}{*}{ I } & 1 & 68.84 & 0.12 & 31.04 & Lempung Liat Berpasir & 1.12 & 29 \\
\hline & 2 & 68.96 & 0.13 & 30.91 & Lempung Liat Berpasir & 1.13 & 29 \\
\hline & 3 & 70.52 & 0.32 & 29.16 & Lempung Liat Berpasir & 1.48 & 29 \\
\hline & 4 & 67.89 & 0.29 & 31.82 & Lempung Liat Berpasir & 1.31 & 30 \\
\hline & 5 & 67.28 & 0.4 & 32.32 & Lempung Liat Berpasir & 1.08 & 30 \\
\hline & 6 & 69.2 & 0.37 & 30.43 & Lempung Liat Berpasir & 1.38 & 29 \\
\hline \multirow{6}{*}{ II } & 1 & 70.1 & 0.25 & 29.65 & Lempung Liat Berpasir & 1.26 & 30 \\
\hline & 2 & 68.92 & 0.32 & 30.76 & Lempung Liat Berpasir & 1.6 & 30 \\
\hline & 3 & 69.32 & 0.28 & 30.4 & Lempung Liat Berpasir & 1.41 & 30 \\
\hline & 4 & 67.2 & 0.28 & 32.52 & Lempung Liat Berpasir & 1.48 & 30 \\
\hline & 5 & 67.9 & 0.31 & 31.79 & Lempung Liat Berpasir & 1.49 & 29 \\
\hline & 6 & 67.08 & 0.12 & 32.8 & Lempung Liat Berpasir & 0.28 & 30 \\
\hline \multirow{6}{*}{ III } & 1 & 69.6 & 0.36 & 30.04 & Lempung Liat Berpasir & 0.88 & 30 \\
\hline & 2 & 68.3 & 0.35 & 31.35 & Lempung Liat Berpasir & 1.36 & 30 \\
\hline & 3 & 68 & 0.36 & 31.64 & Lempung Liat Berpasir & 2.32 & 29 \\
\hline & 4 & 63.2 & 0.25 & 36.55 & Liat Berpasir & 1.2 & 29 \\
\hline & 5 & 63.04 & 0.28 & 36.68 & Liat Berpasir & 1.4 & 30 \\
\hline & 6 & 63.3 & 0.3 & 36.4 & Liat Berpasir & 1.43 & 30 \\
\hline
\end{tabular}

Berdasarkan hasil penelitian yang telah dilakukan dapat dilihat bahwa tekstur sedimen pada lokasi penelitian memiliki komposisi yang dominan yaitu lempung liat berpasir. Sedangkan tiga titik pengambilan data yang berbeda tekstur sedimennya yaitu liat berpasir. Hasil penelitian yang telah dilakukan dapat dilihat bahwa bahan organik sedimen pada stasiun 1 berkisar antara 1,08 - 1,48\%, stasiun 2 berkisar antara 0,28 - 1,6\%, sedangkan stasiun 3 berkisar antara $0,88-2,32 \%$. Serta hasil pengukuran salinitas sedimen yang telah dilakukan, nilai salinitas stasiun 1,2 , dan 3 berkisar antara 29-30 ppt. 
Analisa PCA (Principal Component Analysis)

Hasil analisis PCA terhadap tekstur sedimen dengan kerapatan mangrove (stasiun 1) di kawasan pesisir Desa Timbulsloko, Demak dapat dilihat pada Tabel 3 Rotated Component Matrix sebagai berikut:

Tabel 3. Rotated Component Matrix Stasiun 1

\begin{tabular}{lcc}
\hline & \multicolumn{2}{c}{ Component } \\
\cline { 2 - 3 } & 1 & 2 \\
\hline Clay & $\underline{-0.951}$ & 0.253 \\
Sand & $\underline{0.918}$ & -0.354 \\
Bahan_organik & $\underline{0.9}$ & 0.253 \\
Silt & 0.191 & $\underline{0.975}$ \\
Kerapatan & -0.389 & $\underline{0.769}$ \\
Salinitas & -0.618 & $\underline{0.647}$ \\
\hline
\end{tabular}

Peta analisa PCA terhadap parameter jenis sedimen dengan kondisi hutan mangrove di pesisir Desa Timbulsloko, Demak dari data tabel Rotated Component Matrix adalah sebagai berikut :

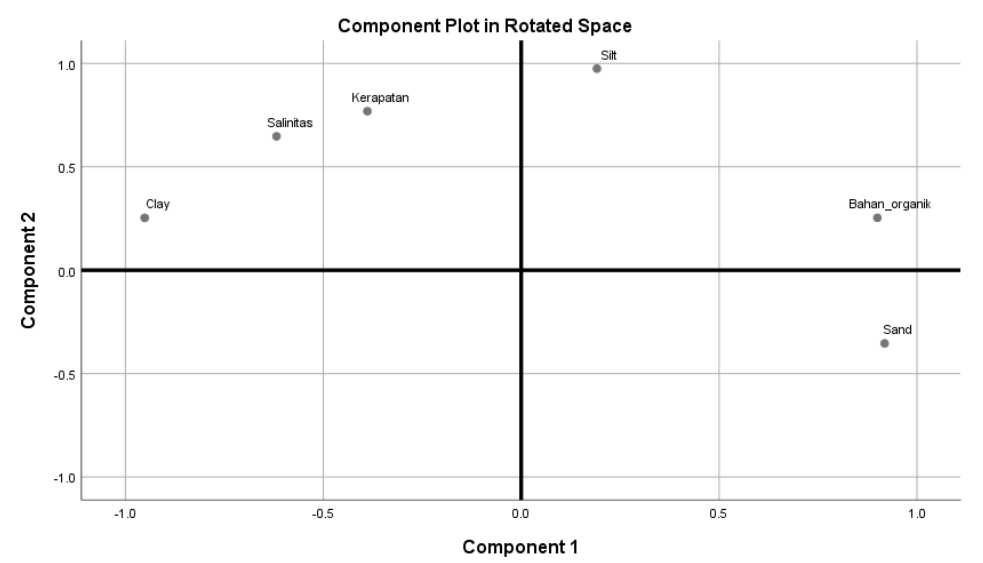

Gambar 3. Peta Analisa PCA Terhadap Parameter Jenis Sedimen dengan Kondisi Hutan Mangrove di Pesisir Desa Timbulsloko, Demak

Berdasarkan peta di atas, komponen 1 memiliki kontribusi sebesar 60,60\% dan komponen 2 memiliki kontribusi sebesar $28,42 \%$ Nilai tersebut berarti sebesar $60,60 \%$ dari jumlah variabel dapat dijelaskan oleh faktor pertama dan sebesar $28,42 \%$ dari jumlah variabel dapat dijelaskan oleh faktor kedua. Berdasarkan nilai loading factor dapat diketahui bahwa ada keterkaitan antara lumpur (silt), salinitas sedimen, dan kerapatan mangrove; adapun pasir (sand), liat (clay) dan bahan organik juga memiliki hubungan keterkaitan. Hal tersebut menunjukkan bahwa keberadaan lumpur (silt) yang ada dalam komposisi tekstur sedimen memungkinkan mangrove jenis Rhizhopora sp. untuk tumbuh. Sedangkan pada stasiun 1 fraksi pasir mendominasi komposisi tekstur sedimen, maka mangrove yang akan banyak tumbuh adalah jenis Avicennia sp..

Hasil analisis PCA terhadap tekstur sedimen dengan kerapatan mangrove (stasiun 2) di kawasan pesisir Desa Timbulsloko, Demak dapat dilihat pada Tabel 4 Rotated Component Matrix sebagai berikut:

Tabel 4. Rotated Component Matrix Stasiun 2

\begin{tabular}{lcc}
\hline & \multicolumn{2}{c}{ Component } \\
\cline { 2 - 3 } & 1 & 2 \\
\hline Bahan_organik & $\underline{0.971}$ & 0.235 \\
Silt & $\underline{0.97}$ & 0.18 \\
Kerapatan & $\underline{-0.831}$ & -0.526 \\
Sand & 0.186 & $\underline{0.968}$ \\
Clay & -0.239 & $\underline{-0.956}$ \\
Salinitas & 0.459 & $\underline{0.628}$ \\
\hline
\end{tabular}

Peta analisa PCA terhadap parameter jenis sedimen dengan kondisi hutan mangrove di pesisir Desa Timbulsloko, Demak dari data tabel Rotated Component Matrix adalah sebagai berikut : 


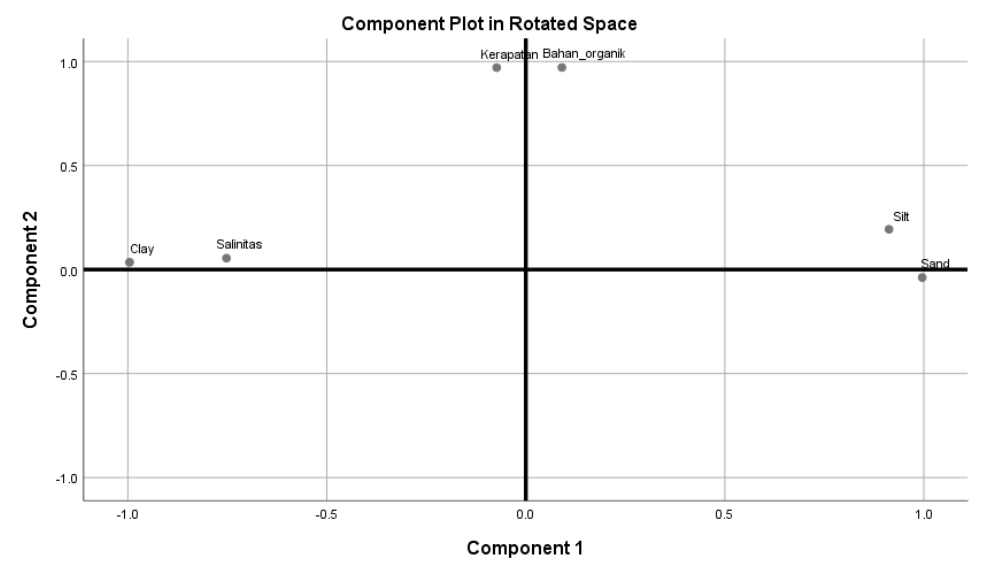

Gambar 4. Peta Analisa PCA Terhadap Parameter Jenis Sedimen dengan Kondisi Hutan Mangrove di Pesisir Desa Timbulsloko, Demak

Berdasarkan peta di atas, komponen 1 memiliki kontribusi sebesar 71,43\% dan komponen 2 memiliki kontribusi sebesar $20,02 \%$. Nilai tersebut berarti sebesar $71,43 \%$ dari jumlah variabel dapat dijelaskan oleh faktor pertama dan sebesar $20,02 \%$ dari jumlah variabel dapat dijelaskan oleh faktor kedua. Berdasarkan nilai loading factor dapat diketahui bahwa ada keterkaitan antara bahan organik, lumpur (silt), dan kerapatan mangrove; adapun pasir (sand), liat (clay), dan salinitas juga memiliki hubungan keterkaitan. Hal tersebut menunjukkan bahwa keberadaan lumpur (silt) yang ada dalam komposisi tekstur sedimen memungkinkan mangrove jenis Rhizhopora sp. untuk tumbuh. Sedangkan pada stasiun 2 fraksi pasir mendominasi komposisi tekstur sedimen, maka mangrove yang akan banyak tumbuh adalah jenis Avicennia sp..

Hasil analisis PCA terhadap tekstur sedimen dengan kerapatan mangrove (stasiun 3) di kawasan pesisir Desa Timbulsloko, Demak dapat dilihat pada Tabel 5 Rotated Component Matrix sebagai berikut:

Tabel 5. Rotated Component Matrix Stasiun 3

\begin{tabular}{lcc}
\hline & \multicolumn{2}{c}{ Component } \\
\cline { 2 - 3 } & 1 & 2 \\
\hline Sand & $\underline{0.996}$ & -0.038 \\
Clay & $\underline{-0.996}$ & 0.035 \\
Silt & $\underline{\underline{0.913}}$ & 0.193 \\
Salinitas & $\underline{-0.752}$ & 0.055 \\
Bahan_organik & 0.091 & $\underline{0.971}$ \\
Kerapatan & -0.073 & $\underline{0.971}$ \\
\hline
\end{tabular}

Peta analisa PCA terhadap parameter jenis sedimen dengan kondisi hutan mangrove di pesisir Desa Timbulsloko, Demak dari data tabel Rotated Component Matrix adalah sebagai berikut :

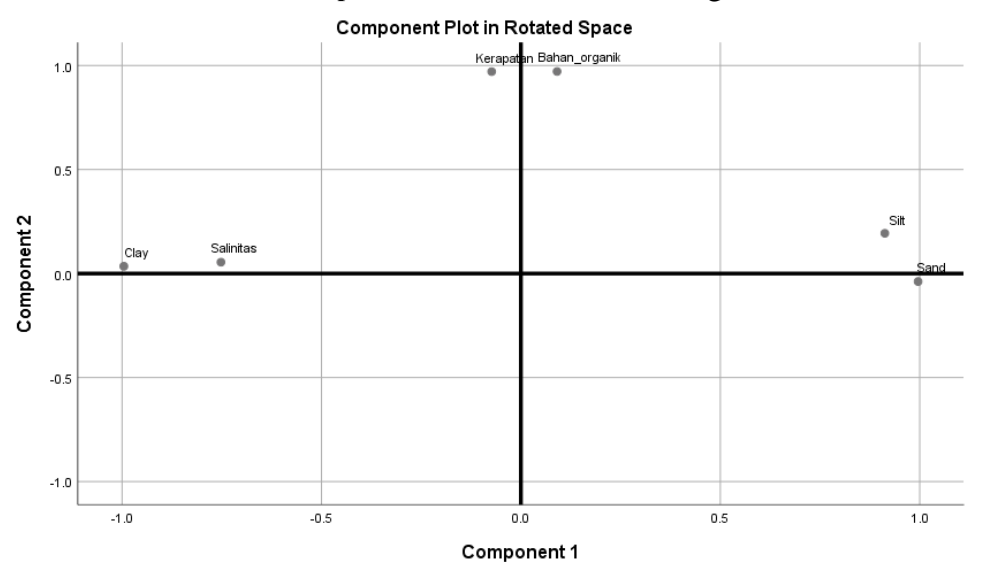

Gambar 5. Peta Analisa PCA Terhadap Parameter Jenis Sedimen dengan Kondisi Hutan Mangrove di Pesisir Desa Timbulsloko, Demak

Berdasarkan peta di atas, komponen 1 memiliki kontribusi sebesar 56,65\% dan komponen 2 memiliki kontribusi sebesar 32,07\%,. Nilai tersebut menunjukkan sebesar 56,65\% dari jumlah variabel dapat dijelaskan oleh faktor pertama dan sebesar 32,07\% dari jumlah variabel dapat dijelaskan oleh faktor kedua. Berdasarkan nilai loading factor dapat diketahui bahwa ada keterkaitan antara lumpur (silt), pasir (sand), liat (clay) dan salinitas sedimen; adapun kerapatan dan bahan organik juga memiliki hubungan keterkaitan. Hal tersebut menunjukkan bahwa keberadaan lumpur (silt), pasir (sand) dan liat (clay) yang ada mempengaruhi pertumbuhan mangrove di lokasi penelitian. Sedangkan pada 
stasiun 3 fraksi pasir mendominasi komposisi tekstur sedimen, maka mangrove yang akan banyak tumbuh adalah jenis Avicennia sp..

Tabel 6. Nilai Total Varians Terjelaskan pada Analisis Faktor

\begin{tabular}{cccc}
\hline \multirow{2}{*}{ Faktor } & \multicolumn{3}{c}{ \% Varians } \\
\cline { 2 - 4 } & Stasiun 1 & Stasiun 2 & Stasiun 3 \\
\hline 1 & 60.60 & 71.43 & 56.65 \\
2 & 28.42 & 20.02 & 32.07 \\
\cline { 2 - 4 } Total & 89.01 & 91.45 & 88.72 \\
\hline
\end{tabular}

Berdasarkan nilai total varians terjelaskan pada analisis faktor atau cumulative variance pada ketiga stasiun, stasiun 1 bernilai sebesar 89,01\%, stasiun 2 bernilai sebesar 91,45\%, dan stasiun 3 bernilai sebesar 88,72\%. Hal ini menunjukkan bahwa ketiga stasiun memiliki nilai cumulative variance di atas 60\%. Menurut Hair et al., (2011), nilai cumulative variance di atas $60 \%$ masuk ke dalam kategori memuaskan sehingga pada hasil analisis faktor stasiun 1, 2, dan 3 sudah memiliki nilai cumulative variance yang memuaskan. Hal ini menunjukkan bahwa pengaruh dari kedua faktor yang terbentuk dari masing-masing stasiun tersebut tinggi terhadap jenis sedimen dan kerapatan mangrove di setiap stasiunnya.

\section{Analisa Regresi Linear Berganda}

Hasil analisa regresi linear berganda stasiun 1 tersaji pada Tabel 7 dan 8 .

Tabel 7. Persamaan Regresi Linear Berganda Stasiun 1

\begin{tabular}{|c|c|c|c|c|c|c|}
\hline \multirow[b]{2}{*}{ Model } & & \multicolumn{2}{|c|}{$\begin{array}{l}\text { Unstandardized } \\
\text { Coefficients }\end{array}$} & \multirow{2}{*}{$\begin{array}{c}\text { Standardized } \\
\text { Coefficients } \\
\text { Beta } \\
\end{array}$} & \multirow[b]{2}{*}{$\mathrm{t}$} & \multirow[b]{2}{*}{ Sig. } \\
\hline & & B & Std. Error & & & \\
\hline \multirow[t]{5}{*}{1} & (Kerapatan) & 14846.89 & 5704.02 & & 2.603 & 0.234 \\
\hline & Silt & 8923.145 & 831.017 & 1.135 & 10.738 & 0.059 \\
\hline & Clay & -630.674 & 223.605 & -0.74 & -2.82 & 0.217 \\
\hline & Bahan Organik & -7346.55 & 1028.25 & -1.274 & -7.145 & 0.089 \\
\hline & Salinitas & 481.549 & 355.756 & 0.264 & 1.354 & 0.405 \\
\hline
\end{tabular}

Berdasarkan Tabel 7 model regresi linear berganda stasiun 1 diperoleh persamaan yaitu $\mathrm{Y}=14846.89+$ $8923.145 \mathrm{bX}_{2}-630.674 \mathrm{X}_{3}-7346.55 \mathrm{X}_{4}+481.549 \mathrm{X}_{5}$. Hasil analisis pada Tabel 7 menunjukkan silt nilai t hitung sebesar 10,738 dengan probabilitas $=0,059>0,05$ artinya silt tidak berpengaruh signifikan, clay nilai t hitung sebesar 2,82 dengan probabilitas $=0,217>0,05$ artinya clay tidak berpengaruh signifikan, bahan organik nilai t hitung sebesar 7,145 dengan probabilitas $0,089>0,05$ artinya bahan organik tidak berpengaruh signifikan terhadap kerapatan mangrove, dan salinitas nilai t hitung sebesar 1,354 dengan probabilitas 0,405 > 0,05 artinya salinitas tidak berpengaruh signifikan terhadap kerapatan mangrove.

Tabel 8. Kesimpulan Model Analisa Regresi Linear Berganda Stasiun 1

\begin{tabular}{ccccc}
\hline Model & R & R Square & R Square & $\begin{array}{c}\text { Adjusted Error of } \\
\text { the Estimate }\end{array}$ \\
\hline 1 & 0.997 & 0.995 & 0.974 & 153.31186 \\
\hline
\end{tabular}

Berdasarkan Tabel 8 diperoleh nilai koefisien korelasi (R) sebesar 0,997 yang berarti hubungan silt, clay, bahan organik dan salinitas dengan kerapatan mangrove dikategorikan berhubungan sangat kuat. Nilai koefisien determinasi $\left(\mathrm{R}^{2}\right)$ sebesar 0,995 nilai ini menunjukkan sebesar 99,5\% kerapatan mangrove stasiun 1 dipengaruhi oleh silt, clay, bahan organik dan salinitas, sisanya sebesar $0,05 \%$ dipengaruhi oleh faktor lain seperti faktor fisika kimia yang ada pada perairan.

Hasil analisa regresi linear berganda stasiun 2 tersaji pada Tabel 9 dan 10.

Tabel 9. Persamaan Regresi Linear Berganda Stasiun 2

\begin{tabular}{|c|c|c|c|c|c|c|}
\hline \multirow[b]{2}{*}{ Model } & & \multicolumn{2}{|c|}{$\begin{array}{c}\text { Unstandardized } \\
\text { Coefficients }\end{array}$} & \multirow{2}{*}{$\begin{array}{c}\begin{array}{c}\text { Standardized } \\
\text { Coefficients }\end{array} \\
\text { Beta }\end{array}$} & \multirow[b]{2}{*}{$t$} & \multirow[b]{2}{*}{ Sig. } \\
\hline & & B & Std. Error & & & \\
\hline \multirow[t]{5}{*}{2} & (Kerapatan) & -59760 & 37655.08 & & -1.587 & 0.358 \\
\hline & Silt & 49118.69 & 36127.21 & 1.287 & 1.36 & 0.404 \\
\hline & Clay & 864.842 & 284.295 & 0.388 & 3.042 & 0.202 \\
\hline & Bahan Organik & -11241.6 & 5207.948 & -1.977 & -2.159 & 0.276 \\
\hline & Salinitas & 1288.066 & 1066.494 & 0.189 & 1.208 & 0.44 \\
\hline
\end{tabular}

Berdasarkan Tabel 9 model regresi linear berganda stasiun 2 diperoleh persamaan yaitu $\mathrm{Y}=-59760+$ $49118.69 \mathrm{bX}_{2}+864.842 \mathrm{X}_{3}-11241.6 \mathrm{X}_{4}+1288.066 \mathrm{X}_{5}$. Hasil analisis pada Tabel 9 menunjukkan silt nilai $\mathrm{t}$ hitung sebesar 1,36 dengan probabilitas $=0,404>0,05$ artinya silt tidak berpengaruh signifikan, clay nilai t hitung sebesar 3,042 dengan probabilitas $=0,202>0,05$ artinya clay tidak berpengaruh signifikan, bahan organik nilai t hitung sebesar $-2,159$ dengan probabilitas $0,276>0,05$ artinya bahan organik tidak berpengaruh signifikan terhadap kerapatan

\footnotetext{
${ }^{\circledR}$ Copyright by Management of Aquatic Resources (MAQUARES)
} 
mangrove dan salinitas nilai t hitung sebesar 1,208 dengan probabilitas 0,44 $>0,05$ artinya salinitas tidak berpengaruh signifikan terhadap kerapatan mangrove.

Tabel 10. Kesimpulan Model Analisis Regresi Linear Berganda Stasiun 2

\begin{tabular}{ccccc}
\hline Model & R & R Square & $\begin{array}{c}\text { Adjusted } \\
\text { R Square }\end{array}$ & $\begin{array}{c}\text { Std. Error of } \\
\text { the Estimate }\end{array}$ \\
\hline 2 & 0.994 & 0.989 & 0.943 & 662.01691 \\
\hline
\end{tabular}

Berdasarkan Tabel 10 diperoleh nilai koefisien korelasi (R) sebesar 0,994 yang berarti hubungan silt, clay, bahan organik dan salinitas dengan kerapatan mangrove dikategorikan berhubungan sangat kuat. Nilai koefisien determinasi $\left(\mathrm{R}^{2}\right)$ sebesar 0,989 nilai ini menunjukkan sebesar 98,9\% kerapatan mangrove stasiun 2 dipengaruhi oleh silt, clay, bahan organik dan salinitas, sisanya sebesar $1,1 \%$ dipengaruhi oleh faktor lain seperti faktor fisika kimia yang ada pada perairan.

Hasil analisa regresi linear berganda stasiun 3 tersaji pada Tabel 11 dan 12.

Tabel 11. Persamaan Regresi Linear Berganda Stasiun 3

\begin{tabular}{|c|c|c|c|c|c|c|}
\hline \multirow[b]{2}{*}{ Model } & & \multicolumn{2}{|c|}{$\begin{array}{l}\text { Unstandardized } \\
\text { Coefficients }\end{array}$} & \multirow{2}{*}{$\begin{array}{c}\begin{array}{c}\text { Standardized } \\
\text { Coefficients }\end{array} \\
\text { Beta }\end{array}$} & \multirow[b]{2}{*}{$t$} & \multirow[b]{2}{*}{ Sig. } \\
\hline & & B & Std. Error & & & \\
\hline \multirow[t]{5}{*}{3} & (Kerapatan) & 508103.4 & 133264.1 & & 3.813 & 0.163 \\
\hline & Sand & -4321.74 & 1164.29 & -2.841 & -3.712 & 0.168 \\
\hline & Silt & 301042.9 & 84631.86 & 3.048 & 3.557 & 0.174 \\
\hline & Bahan Organik & -3374.1 & 3415.701 & -0.351 & -0.988 & 0.504 \\
\hline & Salinitas & -10209.2 & 2774.762 & -1.141 & -3.679 & 0.169 \\
\hline
\end{tabular}

Berdasarkan Tabel 11 model regresi linear berganda stasiun 3 diperoleh persamaan yaitu $\mathrm{Y}=508103.4$ $4321.74 \mathrm{bX}_{1}+301042.9 \mathrm{X}_{2}-3374.1 \mathrm{X}_{4}-10209.2 \mathrm{X}_{5}$. Hasil analisis pada tabel menunjukkan sand nilai t hitung sebesar $-3,712$ dengan probabilitas $=0,168>0,05$ artinya sand tidak berpengaruh signifikan, silt nilai t hitung sebesar 3,557 dengan probabilitas $=0,174>0,05$ artinya silt tidak berpengaruh signifikan, bahan organik nilai t hitung sebesar $-0,988$ dengan probabilitas 0,504 > 0,05 artinya bahan organik tidak berpengaruh signifikan terhadap kerapatan mangrove dan salinitas nilai t hitung sebesar -3,679 dengan probabilitas $0,169>0,05$ artinya salinitas tidak berpengaruh signifikan terhadap kerapatan mangrove.

Tabel 12. Kesimpulan Model Analisis Regresi Linear Berganda Stasiun 3

\begin{tabular}{ccccc}
\hline Model & R & R Square & $\begin{array}{c}\text { Adjusted } \\
\text { R Square }\end{array}$ & $\begin{array}{c}\text { Std. Error of } \\
\text { the Estimate }\end{array}$ \\
\hline 3 & 0.994 & 0.988 & 0.939 & 1138.81314 \\
\hline
\end{tabular}

Berdasarkan Tabel 12 diperoleh nilai koefisien korelasi (R) sebesar 0,994 yang berarti hubungan sand, silt, bahan organik dan salinitas dengan kerapatan mangrove dikategorikan berhubungan sangat kuat. Nilai koefisien determinasi $\left(\mathrm{R}^{2}\right)$ sebesar 0,988 nilai ini menunjukkan sebesar 98,8\% kerapatan mangrove stasiun 2 dipengaruhi oleh sand, silt, bahan organik dan salinitas, sisanya sebesar 1,2\% dipengaruhi oleh faktor lain seperti faktor fisika kimia yang ada pada perairan.

\section{Hubungan Tekstur Sedimen dengan Kerapatan Mangrove}

Berdasarkan hasil analisa dengan menggunakan Principal Component Analysis (PCA), pada stasiun 1 butiran sedimen berupa lumpur berkorelasi positif dengan nilai kerapatan mangrove, sedangkan liat berkorelasi positif dengan pasir dan bahan organik. Pada stasiun 2 butiran sedimen lumpur berkorelasi positif dengan kerapatan mangrove dan bahan organik, sedangkan pasir berkorelasi positif dengan liat dan salinitas. Hal tersebut mungkin dapat diartikan bahwa keberadaan lumpur yang ada dalam komposisi tekstur sedimen memungkinkan mangrove jenis Rhizhopora sp. untuk tumbuh. Sedangkan pada stasiun 1 dan 2, fraksi pasir dan liat mendominasi komposisi tekstur sedimen dengan mangrove yang banyak tumbuh adalah jenis Avicennia sp.. Hal ini dapat diartikan bahwa spesies Avicennia sp. dapat beradaptasi dengan keberadaan substrat pasir dan liat untuk dijadikan tempat tumbuh yang baik. Pada stasiun 3 butiran lumpur, pasir, liat dan salinitas sedimen saling berkorelasi positif, sedangkan kerapatan berkorelasi positif dengan bahan organik. Hal tersebut menunjukkan bahwa keberadaan lumpur, pasir, dan liat yang ada mempengaruhi pertumbuhan mangrove di lokasi penelitian. Sedangkan pada stasiun 3 fraksi pasir dan liat mendominasi komposisi tekstur sedimen, dapat diartikan mangrove yang akan banyak tumbuh adalah jenis Avicennia sp..

Berdasarkan hasil analisa dengan menggunakan regresi linear berganda, nilai R pada stasiun 1 sebesar 0,997, stasiun 2 sebesar 0,994, dan stasiun 3 sebesar 0,994. Hal ini menunjukkan jenis sedimen berupa lumpur (silt), liat (clay), bahan organik, dan salinitas memiliki hubungan sangat kuat dengan kerapatan mangrove di stasiun 1, sedangkan di stasiun 2 lumpur (silt), liat (clay), bahan organik, dan salinitas memiliki hubungan sangat kuat terhadap kerapatan mangrove serta stasiun 3 pasir (sand), lumpur (silt), bahan organik, dan salinitas memiliki hubungan sangat kuat terhadap kerapatan mangrove. Hal tersebut dapat diartikan bahwa dari ke- 3 stasiun komposisi sedimen yang kaya akan lumpur akan menjadi tempat tumbuh yang baik untuk mangrove dengan jenis Rhizophora sp., sedangkan untuk substrat yang memiliki kandungan liat (clay) dan pasir (sand) biasanya menjadi tempat tumbuh yang baik untuk mangrove jenis

\footnotetext{
${ }^{\odot}$ Copyright by Management of Aquatic Resources (MAQUARES)
} 
Avicennia sp.. Kandungan pasir (sand) mendominasi di semua stasiun pengamatan, hal tersebut dapat disebabkan karena letak lokasi kawasan mangrove yang dekat dengan pantai yang memiliki arus dan gelombang tinggi. Namun jika dilihat dari nilai signifikansi pada ketiga stasiun menunjukkan hasil yang tidak signifikan. Hal ini dikarenakan data yang diperoleh belum cukup untuk mewakili secara keseluruhannya dan perlu dilakukan observasi atau penelitian lebih lanjut.

\section{KESIMPULAN}

Kesimpulan yang dapat diambil dari penelitian Hubungan Jenis Sedimen dengan Kerapatan Vegetasi Mangrove di Desa Timbulsloko, Demak ini adalah sebagai berikut :

1. Jenis sedimen pada stasiun 1 didominasi oleh tekstur pasir dengan persentase rata-rata $68.78 \%$, stasiun 2 didominasi oleh tekstur pasir dengan persentase rata-rata $68.42 \%$ dan stasiun 3 didominasi oleh tekstur pasir dengan persentase rata-rata 65.91\%. Bahan organik sedimen pada stasiun 1 berkisar antara 1,08 - 1,48\%, stasiun 2 berkisar antara 0,28 - 1,6\%, sedangkan stasiun 3 berkisar antara 0,88-2,32\%.. Salinitas sedimen pada ketiga stasiun berkisar antara 29-30\%.

2. Kerapatan mangrove di lokasi penelitian Desa Timbulsloko didominasi oleh jenis mangrove Avicennia sp.. Nilai kerapatan mangrove stasiun 1 berkisar 2066 - 4550 pohon/ha, stasiun 2 kerapatan mangrove berkisar 2519 - 10000 pohon/ha, dan stasiun 3 kerapatan mangrove berkisar 5986 - 18511 pohon/ha. Kondisi tersebut tergolong baik dan padat.

3. Hubungan jenis sedimen dengan kerapatan mangrove jika dilihat dari analisa PCA berdasarkan nilai loading factor kedua faktor pada stasiun 1, 2, dan 3 menunjukkan tingginya korelasi antar variabel, sedangkan jika dilihat dari hasil analisa regresi linear berganda menunjukkan bahwa hubungan jenis sedimen dengan kerapatan mangrove di stasiun 1 mempunyai hubungan yang sangat kuat dengan angka koefisien determinasi (R2) sebesar 99,5\%, stasiun 2 mempunyai hubungan yang sangat kuat dengan angka koefisien determinasi (R2) sebesar 98,9\%, dan stasiun 3 mempunyai hubungan sangat kuat dengan angka koefisien determinasi (R2) sebesar $98,8 \%$.

\section{UCAPAN TERIMAKASIH}

Ucapan terimakasih ditujukan kepada Dr. Ir. Max Rudolf Muskananfola, M.Sc dan Ir. Anhar Solichin, M.Si yang telah memberikan saran dan kritik yang sangat bermanfaat bagi penulis. Kepada semua pihak yang telah membantu sehingga penulis dapat menyelesaikan artikel ini.

\section{DAFTAR PUSTAKA}

Arisandy, K.R., E.Y. Herawati, dan E. Suprayitno. 2012. Akumuluasi Logam Berat Timbal (Pb) dan Gambaran Histologi pada Jaringan Avicennia marina (forsk.) Vierh di Perairan Pantai Jawa Timur. Jurnal Penelitian Perikanan., 1(1) : 15-25.

Astra, A.S., E.K. Sabarini, A.M. Harjo, dan M.B. Maulana. 2014. Keterlibatan Masyarakat dalam Pengelolaa Kawasan Pesisir dan Laut (Studi Kasus : Kawasan Perlindungan Pesisir Desa Timbulsloko, Kecamatan Sayung, Kabupaten Demak). Wetlands International Indonesia. Bogor.

Buchanan, J. B. 1971. Sediment Analisis.In Holme and McLntryre.Method for Study of Marine Benthos. Blackhel Scientific Publication. London.

Damaywanti, K. 2013. Dampak Abrasi Pantai Terhadap Lingkungan Sosial (Studi Kasus di Desa Bedono, Sayung, Demak). Prosiding Seminar Nasional Pengelolaan Sumberdaya Alam dan Lingkungan. Universitas Diponegoro. Semarang.

Dinas Kelautan dan Perikanan Kabupaten Demak. 2015. Kondisi Daerah Pesisir/Pantai, Portal Sistem Informasi Potensi Daerah Kabupaten Demak.

Hair, J.F., Black, W.C., Babin, B.J., dan Anderson, R.E. 2011. Multivariate Data Analysis. Fifth Edition. New Jersey. PrenticeHall, Inc.

Hendro, G., T.B. Adji, dan N.A. Setiawan. 2012. Penggunaan Metodologi Analisa Komponen Utama (PCA) untuk Mereduksi Faktor-Faktor yang Mempengaruhi Penyakit Jantung Koroner. Science, Engineering, and Technology

Mitchell, K. 2007. Quantitative Analysis by The Point-Centered Quarter Method. Department of Mathematics and Computer Science Hobart and William Smith Colleges. Geneva. New York.

Munandar, R.K., Muzahar, A. Pratomo. 2014. Karakteristik Sedimen di Perairan Desa Tanjung Momong Kecamatan Siantan, Kabupaten Kepulauan Anambas. Universitas Maritim Raja Ali Haji. Kepulauan Riau.

Nontji, A. 2002. Laut Nusantara. Djambatan. Jakarta.

Setyawan, A.D., Susilowati, A. Sutarno. 2002. Biodiversitas Genetik, Spesies dan Ekosistem Mangrove di Jawa. Universitas Sebelas Maret. Surakarta.

Susiana. 2011. Diversitas dan Kerapatan Mangrove, Gastropoda, dan Bivalvia di Estuari Perancak, Bali. Universitas Hassanudin. Makassar.

Syah, C. 2011. Pertumbuhan Tanaman Bakau (Rhizopora mucronata) pada Lahan Restorasi Mangrove di Hutan Lindung Angke Kapuk Provinsi DKI Jakarta. Institut Pertanian Bogor. Bogor. 